\title{
Dampak Implementasi International Financial Reporting Standard Pada Penyajian Other Comprehensive Income Perusahaan Perdagangan, Jasa, dan Investasi di Indonesia
}

\author{
Denny Rianto ${ }^{1}$, Nurmala Ahmar ${ }^{2}$ \\ ${ }^{1}$ Universitas ... \\ ${ }^{2}$ STIE Perbanas Surabaya, Jl. Ngindom Semolo No. 34-36, Surabaya, Jawa Timur 60118
}

INFO ARTIKEL

JEL Classsification:

M41

M48

Keywords:

other comprehensive

income, asset

revaluation, hedging,

association, joint

venture, actuarial,

foreign currency

translation

\section{ABSTRACT}

The purpose of this study is to analyze the presentation of other comprehensive income and its components in the trade, service and investment industries after the implementation of the International Financial Reporting Standard in Indonesia. The sample is the trade, service and investment industry sectors listed in Indonesia Stock Exchange 2012-2015. Other Comprehensive Income (OCI) shall be presented separately in the statements of income since 2013 and re-review for 2012 on the reporting of the relevant year. The components presented include asset revaluation, translation offoreign currency financial statements to reporting currency, actuarial changes in defined benefit obligations, changes in fair value in available-for-sale investments, fair value changes to current, joint and joint venture hedges. The result of the research shows that there is difference of presentation value of other comprehensive comprehensive component. Future research can examine the antecedents and consequent accounts of OCI components in public companies in Indonesia.

\begin{abstract}
ABSTRAK
Tujuan penelitian ini adalah menganalisis penyajian other comprehensive income dan komponennya pada industri perdagangan, jasa, dan investasi pasca penerapan International Financial Reporting Standard di Indonesia. Sampel adalah sektor industri perdagangan, jasa, dan investasi yang terdaftar di Bursa Efek Indonesia tahun 2012-2015. Other Comprehensive Income (OCI) wajib disajikan secara terpisah pada laporan laba rugi sejak tahun 2013 dan saji ulang untuk tahun 2012 pada pelaporan tahun yang besangkutan. Komponen yang disajikan mencakup revaluasi aset, penjabaran laporan keuangan mata uang asing ke mata uang pelaporan, perubahan aktuarial dalam imbalan kerja manfaat pasti, perubahan nilai wajar dalam investasi yang tersedia untuk dijual, perubahan nilai wajar terhadap lindung nilai arus, asosiasi dan ventura bersama. Hasil penelitian menunjukkan terdapat perbedaan nilai penyajian komponen other comprehensive income. Riset mendatang dapat meneliti anteseden dan konsekuen akun komponen OCI pada perusahaan public di Indonesia.
\end{abstract}

*Email Korespondensi: ${ }^{1}$ denny.rianto@gmail.com, ${ }^{2}$ nurmala@perbanas.ac.id 


\section{Pendahuluan}

Akuntansi dapat diartikan sebagai sistem informasi yang menyediakan laporan untuk para pemangku kepentingan mengenai aktivitas ekonomi dan kondisi perusahaan (Warren, 2014). Informasi yang lengkap, akurat, tepat waktu, dan benar di dalam laporan keuangan akan menghindarkan kecurangan akuntansi (accounting fraud). Global Economy Crime Survey pada tahun 2016 yang dilakukan Price Waterhouse Cooper memperlihatkan bahwa kejahatan ekonomi yang paling banyak dilakukan secara global termasuk Indonesia di dalamnya, dalam posisi lima besar adalah kecurangan akuntansi (accounting fraud). Secara global dalam survei tersebut bahkan kecurangan akuntansi mengalami peningkatan dari sisi kuantitas dari 18\% di tahun 2014 menjadi 22\% di tahun 2016.

Hal ini mendorong pihak berkepentingan di dalam profesi akunting baik di tingkat global maupun tingkat nasional Indonesia untuk selalu berbenah diri dalam meningkatkan kualitas laporan keuangan sebagai informasi yang dapat melayani kebutuhan investor dalam mengambil keputusan. Prihadi (2010) mengatakan secara umum terdapat dua kelompok model pelaporan keuangan, yaitu pendekatan kinerja ekonomi (economic performance report), pendekatan hukum pajak dan perdagangan (commercial and tax law approach). Pendekatan pertama ditujukan untuk menyusun laporan keuangan perusahaan yang pada prinsipnya mendasarkan pada kinerja ekonomi dari entitas pelapor. Dengan cara seperti ini investor dapat membuat keputusan tentang investasi. Pendekatan kedua mendasarkan pada peraturan pada peraturan pelaporan yang secara sengaja tidak berpihak pada kinerja ekonomi, tetapi pada ketaatan peraturan pajak di negara tersebut. Indonesia termasuk ke dalam kelompok pendekatan yang pertama.

Perbedaan pendekatan pelaporan keuangan di setiap negara di dunia, tentu saja menghambat globalisasi yang mendasar pada pergerakan informasi dan perpindahan modal. Walaupun pendekatan yang dilakukan dua negara sama dalam hal pelaporan keuangan, tidak menjamin pelaporan keuangan kedua negara tersebut dapat diperbandingkan. Hal ini terjadi karena pilihan metode yang berbeda mengenai pelaporan dan aturan yang tidak seragam antar negara, meskipun prinsip sama dapat saja detailnya berbeda.

Perbedaan-perbedaan di atas membutuhkan satu standard pelaporan keuangan internasional dan pada tahun 2005 muncul International Financial Reporting Standard (IFRS) yang merupakan standar akuntansi yang dibuat oleh International Accounting Standard Board (IASB) yang berkududukan di London Inggris. Indonesia yang tergabung dalam G20 berkomitmen untuk mengadopsi IFRS yang menjadi standar akuntansi yang dipakai oleh negara-negara di Eropa dan menjadi standar global.

Penerapan IFRS di Indonesia berlaku efektif pada tanggal 1 Januari 2012 merupakan konvergensi IFRS tahap pertama dan PSAK (Pernyataan Standar Akuntansi Keuangan) yang ada telah mengadopsi IFRS. PSAK dibuat Dewan Standar Akuntansi Keuangan (DSAK) yang merupakan bagian dari Ikatan Akuntan Indonesia (IAI). Konvergensi IFRS terus berlangsung di tahun 2013 dan 2014 sebagai konvergensi tahap kedua. Konvergensi tahap kedua ini diharapkan semakin meminimalkan perbedaan standar akuntansi keuangan di Indonesia dengan IFRS.

Ahalik (2015) mengatakan bahwa IFRS memiliki karakteristik berbasis prinsip (Principle based), dimana Principle based memberikan acuan secara umum bagaimana transaksi akuntansi diterapkan, banyak menggunakan 'professional judgment', banyak pengungkapan dalam catatan atas laporan keuangan, perubahan dalam hal nama laporan keuangan, dimana terdapat dua perubahan dalam hal judul laporan keuangan yaitu Laporan Laba Rugi dan Penghasilan Komprehensif Lain 
(Income Statement \& Other Comprehensive Income) yang sebelumnya adalah Laporan Laba Rugi (Income Statement) dan Laporan Posisi Keuangan (Statement of Financial Position) yang sebelumnya adalah Neraca (Balance Sheet), munculnya perkiraan Laba Komprehensif Lain (Other Comprehensive Income-OCI), dimana perkiraan OCI bukanlah hal baru dalam PSAK sebelumnya, namun OCI dalam IFRS muncul dari lebih banyak transaksi yang berkaitan dengan penilaian terhadap nilai wajar seperti revaluasi aset tetap (PSAK 16), penjabaran laporan keuangan mata uang asing ke mata uang pelaporan (PSAK 10), perubahan actuarial dalam imbalan kerja manfaat pasti (PSAK 24), perubahan nilai wajar dalam investasi yang tersedia untuk dijual (PSAK 55), serta perubahan nilai wajar terhadap lindung nilai arus kas (PSAK 55), asosiasi dan ventura (PSAK 15).

Penerapan International Financial Reporting Standard (IFRS) dalam semua sektor industri pada perusaahaan-perusahaan di Indonesia khususnya perusahaan yang telah listing di Bursa Efek Indonesia, membuat emiten di Indonesia memiliki daya banding laporan keuangan yang lebih baik, dapat mengurangi hambatan investasi, meningkatkan transparansi perusahaan, dan mengurangi biaya modal perusahaan. Penelitian ini bertujuan menginvestigasi komponen OCI pada perusahaan perdagangan, jasa dan investigasi agar dapat diketahui komponen OCI manakah yang banyak disajikan pada sector industry tersebut.

\section{Telaah Teori dan Pengembangan Hipotesis}

Teori sinyal menurut Bringham dan Houston (2001: 39), merupakan suatu tindakan yang diambil manajemen perusahaan yang memberi petunjuk bagi investor tentang bagaimana manajemen memandang prospek perusahaan Komponen-komponen dalam Laporan pendapatan komprehensif lain (OCI) yang mencakup keuntungan atau kerugian yang belum direalisasi antara lain : (1) revaluasi aset tetap berwujud dan aset tidak berwujud, (2) selisih kurs mata uang asing, (3) perubahan investasi dalam sekuritas yang dikatagorikan sebagai tersedia untuk dijual, (4) penyesuaian liabilitas minimum pensiun, (5) lindung nilai arus kas, (6) bagian dari entitas asosiasi dan ventura bersama yang di catat dengan menggunakan metode ekuitas dalam OCI.

Menurut pendapat Hasnawati (2005), signalling theory menyatakan pengeluaran investasi memberikan sinyal positif tentang pertumbuhan perusahaan dimasa yang akan datang, sehingga meningkatkan harga saham indikator nilai perusahaan. Dalam arti lain bahwa teori sinyal memberikan gambaran informasi yang dimuat didalamnya memiliki peran yang penting bagi investor dalam mengambil keputusan investasinya. Tepri sonyal pada prnrlitian ini menjelaskan bahwa manajemen sebagai pihak yang memberikan sinyal berupa informasi laba dalam laporan keuangan, yang khususnya terkait pelaporan pendapatan komprehensif lain dilihat dari komponenkomponen yang mempengaruhi pendapatan komprehensif lain (OCI).

PSAK no.1 (Revisi 2009) menyampaikan bahwa perubahan laba rugi menjadi laba rugi komprehensif yaitu menjadikan informasi yang disajikan dalam laporan keuangan menjadi lebih informatif bagi pengambil keputusan, sebelumnya format laporan keuangan bersifat untuk keperluan internal manajemen yang memisahkan laba kotor dan laba opersional, selanjutnya dapat dilihat jelas perubahan dalam laporan keuangan yang sedikit berbeda dalam format penyajian laporan keuangan yang mana dimaksud bahwa pengguna laporann keuangan bersifat umum sehingga dibuat sesederhana dan semudah mungkin di mengerti oleh pengguna.

Laporan laba rugi komprehensif merupakan jumlah dari net income dan item lain yang mengalami perlakukan bypass (pendapatan komprehensif lain) dari laporan keuangan karena item-item ini belum diakui pada laporan 
keuangan termasuk item seperti keuntungn atau kerugian holding karena penjulan sekuritas dan keuntungan atau kerugian karena transaksi mata uang asing atau keuntungan dan kerugian karena revaluasi nilai aktiva tetap. Bagian-bagian diatas menjadi penting dalam laporan pendapatan komprehensif karena bagian tersebut mampu memberikan gambaran atau keadaan yang lebih mendetailkeadaan perusahaan secara keseluruhan.

Velashani (1999), menyatakan bahwa pelaporan keuangan yang menyajikan laba rugi komprehensif merupakan pelaporan yang menyajikan secara keseluruhan dalam penyajian pelaporan ekuitas jika dibandingkan dengan penggunaan metode net income.

\section{Perubahan Selisih Kurs Mata Uang Asing}

PSAK 10 menjabarkan selisih kurs merupakan selisih yang dihasilkan dari penjabaran dalam jumlah tetrtentu suatu mata uang ke dalam mata uang lain pada kurs yang berbeda. Dalam ruang lingkup PSAK 10 dijabarkan laporan keuangan dari kegiatan usaha anak perusahaan diluar negeri pada saat akan dikonsolidasikan ke laporan keuangan perusahaan induk yang mana mata uang pelaporan keuangan perusahaan anak berbeda dengan laporan keuangan perusahaan induk dan penjabaran laporan keuangan dari suatu entitas ke dalam mata uang penyajian. Bahwa suatu transaksi yang dilakukan dalam mata uang asing (selain mata uang fungsional) akan dicatat dalam mata uang fungsional dengan menggunakan spot rate pada tanggal transaksi.

Prosedur penjabaran dari mata uang fungsional ke mata uang penyajian menurut PSAK 10 paragraf 40 dilakukan dengan, Aset dan liabilities untuk setiap laporan posisi keuangan yang disajikan (termasuk komparatif) dijabarkan menggunakan kurs penutup pada tanggal laporan posisi keuangan tersebut, penghasilan dan beban untuk setiap laporan laba rugi komprehensif atau laporan laba rugi terpisah yang disajikan (termasuk komparatrif) dijabarkan menggunakan kurs pada tanggal transaksi, semua selisih kurs yang dihasilkan diakui dalam pendapatan komprehensif lain (OCI).

\section{Revaluasi Aset Tetap Berwujud dan Aset Tetap Tidak Berwujud}

Berdasarkan PSAK No.16 terkait aset tetap, perusahaan dapat memilih metode penilaian atas aset tetapnya yaitu dengan Cost Method (Metode Biaya) yang artinya perusahaan menyusutkan aset tetapnya tanpa melalukan revaluasi, sebagai konsekuensinya perusahaan menilai apakah terdapat indikasi penurunan nilai sesuai dengan PSAK 48 terkait penurunan nilai aset. Sedangkan OCI muncul apabila perusahaan menggunakan metode revaluasi.

Menurut PSAK No.1 (revisi 2009) komponen perubahan dalam surplus revaluasi aset tetap dan aset tidak berwujud dalam pendapatan komprehensif lain yaitu berdasarkan PSAK-16, aset tetap adalah aset berwujud yang dimiliki untuk digunakan dalam produksi atau penyediaan barang atau jasa untuk direntalkan kepada pihak lain atau untuk tujuan administratif; dan diharapkan untuk digunakan selama lebih dari satu periode. Berdasarkan PSAK-19, aset adalah sumber daya yang dikendalikan oleh entitas sebagai akibat peristiwa masa lalu, dan manfaat ekonomis di masa depan dari asset tersebut diharapkan diterima oleh entitas. Aset dapat diklasifikasikan sebagai aset moneter dan non moneter, dimana aset moneter adalah kas dimiliki dan aset yang akan diterima dalam bentuk kas yang jumlahnya pasti atau dapat ditentukan. Sebaliknya, aset tidak berwujud adalah aset non moneter yang dapat diidentifikasi tanpa wujud fisik. Penjelasan dalam PSAK16 (paragraf 41) terkait pengakuan aset tetap berwujud dan aset tetap tidak berwujud setelah revaluasi menyebutkan "surplus revaluasi aset tetap yang termasuk dalam ekuitas dapat dipindahkan langsung ke saldo laba ketika aset tersebut dihentikan pengakuannya. Dengan kata lain hal tersebut dapat meliputi pemindahan 
sekaligus surplus revaluasi ketika penghentian atau pelepasan aset tersebut.

\section{Lindung Nilai Arus Kas}

Adapun tujuan penerapan instrument lindung nilai dan jenis lindung nilai yaitu untuk memastikan keuntungan atau kerugian atas instrument lindung nilai, dan jenis lindung nilai diakui dalam laporan laba rugi komprehensif periode yang sama. Dalam PSAK-55 lindung nilai arus kas diartikan sebagai perjanjian yang mengikat untuk mempertukarkan sumber daya dalam kualitas tertentu pada tingkat harga tertentu dan pada tanggal atau tanggal-tanggal tertentu dimasa depan. Bahwa diidentifikasikan setiap perusahaan mempunyai resiko yang nantinya akan berpengaruh terhadap kinerja perusahaan apabila aset perusahaan dibandingkan dengan tingkat resiko nilai lindung arus kas secara langsung dan atau secara keseluruhan akan memiliki presentase aset yang dilindungi nilai.

\section{Penyesuaian Program Imbalan Kerja/ Pensiunan}

Menurut Ahanik (2015) Imbalan kerja adalah seluruh bentuk imbalan yang diberikan entitas dalam pertukaran atas jasa yang diberikan oleh pekerja atau untuk terminasi kontrak kerja.

Komponen imbalan kerja yang menghasilkan pendapatan komprehensif lain (OCI) berasal dari program imbalan pasti yaitu berupa keuntungan dan kerugian aktuarial atau perubahan atas nilai kini dari kewajiban imbalan pasti sebagai akibat dari penyesuaian pengalaman (dampak dari perbedaan antara asumsi aktuarial awal dengan apa yang secara aktual terjadi dan pengaruh perubahan asumsi aktuarial.

\section{Perubahan Investasi Aset Keuangan Tersedia Untuk Dijual}

Dalam PSAK-55 (instrument keuangan: pengakuan dan pengukuran) instrument keuangan adalah setiap kontrak yang menambah niali aset keuangan entitas dan liabilitas keuangan atau instrumen ekuitas entitas lain. Yang menjadi instrumen keuangan utama adalah kas, piutang, investasi, utang sedangkan intrumen keuangan turunan (derivative) adalah lindung nilai (hedging) yang terdiri dari forward, futures, options, dan swaps. Instrumen keuangan dapat dikatagorikan menjadi (1) investasi yang akan dipegang sampai jatuh tempo (held to maturity - HTM), (2) investasi yang tersedia untuk dijual (available for sale-AFS atau fair value through other comprehensive income - FVTOCI), (3) investasi yang diperdagangkan (Tranding atau Fair Value Trough Profit \& Loss - FVTPL) dan (4) pinjaman dan piutang.

Sedangkan penjelasan derivatif merupakan suatu instrumen keuangan atau kontrak lain dengan tiga karakteristik yaitu (1) nilainya berubah sebagai akibat dari perubahan variable yang telah ditentukan atau yang sering disebut dengan variabel yang mendasari, (2) tidak memerlukan investasi awal neto atau memerlukan investasi awal neto dalam jumlah yang lebih kecil dibandingkan dengan jumlah yang diperlukan untuk kontrak serupa lain yang diperkirakan akan menghasilkan dampak yang serupa sebagai akibat perubahan faktor pasar, dan yang ke (3) diselesaikan pada tanggal tertentu dimasa depan.

\section{Entitas Asosiasi dan Ventura Bersama}

Nilai investasi pada entitas asosiasi dicatat dengan menggunakan metode ekuitas, dalam metode ekuitas investasi dicatat sebesar biaya perolehan dan dapat bertambah serta berkurang pada saat mengakui bagian laba atau rugi setelah tanggal perolehan. Jenis entitas atau kerja sama lain dalam metode ekuitas adalah perjanjian bersama seperti ventura bersama, dimana masing-masing perusahaan menjalankan aktivitas ekonomi secara bersama namun patuh pada pengendalian bersama.

Entitas asosiasi (associate) adalah suatu entitas, termasuk entitas non-korporasi seperti persekutuan, dimana investor mempunyai pengaruh signifikan dan bukan merupakan 
entitas anak ataupun bagian partisipasi dalam ventura bersama. Dengan kata lain bahwa Entitas asosiasi adalah entitas yang mana Kelompok Usaha memiliki pengaruh signifikan. Pengaruh signifikan adalah kekuasaan untuk berpartisipasi dalam keputusan kebijakan keuangan dan operasional investee, tetapi tidak mengendalikan atau mengendalikan bersama atas kebijakan tersebut

Ventura bersama (joint venture) merupakan perjanjian kontraktual dimana dua atau lebih pihak menjalankan aktivitas ekonomi yang tunduk pada pengendalian bersama, bahwa Ventura bersama adalah pengaturan bersama yang para pihaknya memiliki pengendalian bersama atas pengaturan memiliki hak atas aset neto dari pengaturan. Pengendalian bersama adalah persetujuan kontraktual untuk berbagi pengendalian atas suatu pengaturan, yang ada hanya ketika keputusan tentang aktivitas relevan mensyaratkan persetujuan dengan suara bulat dari seluruh pihak yang berbagi pengendalian

Riset sebelumnya terkait topic sejenis pernah dilakukan oleh Pengujian hipotesis untuk menguji perbedaan penyajian 7 (tujuh) komponen other comprehensive income (OCI) memberikan bukti bahwa 2 (dua) hipotesis terbukti dan 4 (tiga) tidak berhasil dibuktikan. selisih kurs, sekuritas lindung nilai, asosiasi ditemukan adanya perbedaan penyajian pada laporan laba rugi dan penghasilan komprehensif lain. Hipotesis terkait dengan imbalan pasti, aset/aset tidak berwujud tidak ditemukan adanya perbedaan penyajian pada laporan laba rugi dan penghasilan komprehensif lain. Hipotesis ventura bersama tidak dapat disimpulkan karena sampel yang diuji secara keseluruhan tidak menyajikan selisih nilai ventura.

Keterbatasan penelitian ini adalah mengambil satu kelompok sampel sektor industri beserta dengan subsektor-subsektor di dalamnya. Hasil observasi hanya berlaku untuk sektor industri tersebut dan tidak berlaku untuk sektor industri lain yang terdaftar di Bursa Efek Indonesia (BEI). Demikian juga dengan hasil uji beda, temuan perbedaan tidak dapat digeneralisasi untuk keseluruhan sektor industri. Hasil penelitian ini merupakan informasi penting yang dapat digunakan pemerintah sebagai salah satu informasi pendapatan pajak karena selisih nilai komponen Other Comprehensive Income (OCI) dapat dikenai pajak. Bagi investor, hasil penelitian ini memberikan informasi tentang besarnya nilai Other Comprehensive Income (OCI) dimana nilai OCI meskipun secara riil bukan berupa kas namun nilai tersebut dapat merupakan informasi yang mampu menambah nilai perusahaan, misalnya terkait dengan peningkatan nilai asset tetap yang tercermin pada revaluasi asset. Sedangkan bagi peneliti berikutnya, hasil penelitian ini merupakan dasar dilakukannya riset-riset lanjutan terkait Other Comprehensive Income (OCI). Faktor apa yang mempengaruhi OCI dan konsekuensi yang diakibatkan oleh informasi OCI.

Bersadarkan teori dan tujuan penelitian untuk mengetahui karakteristik komponen pendapatan komprehensif lain berdasarkan sector perdagangan, jasa dan investasi, maka hipotesis penelitian adalah sebagai berikut:

$\mathrm{H}_{1}$ : terdapat perbedaan penyajian komponen perubahan selisih kurs mata uang asing pada subsektor perdagangan, jasa, dan investasi.

$\mathrm{H}_{2}$ : terdapat perbedaan penyajian komponen program imbalan kerja berdasarkan subsektor perdagangan, jasa, dan investasi.

$\mathrm{H}_{3}$ : terdapat perbedaan penyajian komponen perubahan investasi aset keuangan yang tersedia untuk dijual berdasarkan subsektor perdagangan, jasa, dan investasi.

$\mathrm{H}_{4}$ : terdapat perbedaan penyajian komponen lindung nilai arus kas berdasarkan subsektor perdagangan, jasa, dan investasi.

$\mathrm{H}_{5}$ : terdapat perbedaan penyajian komponen revaluasi aset tetap berwujud dan tidak berwujud berdasarkan subsektor perdagangan, jasa, dan investasi.

$\mathrm{H}_{6}$ : terdapat perbedaan penyajian komponen asosiasi pada subsektor perdagangan, jasa, dan investasi. 
$\mathrm{H}_{7}$ : terdapat perbedaan penyajian komponen ventura pada subsektor perdagangan, jasa, dan investasi.

Riset tentang penyajian dan pengungkapan penghasilan komprehensif lain dilakukan oleh Anggraini dan Jogiyanto (2017), Kim (2016), Santoso, Ahmar \& Mulyadi (2017), Sidhanta, Ahmar \& Mulyadi (2018), Wahyudi (2017), Shi, wang \& Shu (2017). Penyajian laba komprehensif dengan metode format tunggal disbanding dua format pernyataan terbukti mempengaruhi kebijakan investor. (Du, Steven \& McEnroe, 2015). Terkait dengan pengukuran, Nishikawa, Kamiya \& Kawanishi (2016) mendeskripsikan teknik-teknik pengukuran untuk penghasilan komprehensif lain. Penghasilan komprehensif lain terbukti memiliki nilai relevansi nilai (Gunther, 2015; Praptias \& Harto, 2015; Schaberl \& Vitoravich (2015); Yudiman dan Ahmar (2017). Kandungan relevansi nilai tersebut berdampak pada pengaruh penghasilan komprehensif lain terhadap return dimoderasi oleh kualitas audit (Nugroho \& Januarti, 2016). Bratten, Causholli \& Khan (2016) penyajian penghasilan komprehensif lain dengan menerapkan nilai wajar dapat digunakan untuk mempredikasi laba masa depan bank. Sementara Gazzola \& Amelio bahkan menemukan bukti pengaruh laba komprehensif pada rasio-rasio keuangan selama periode krisis yang disebabkan oleh peran penting penghasilan komprehensif lain dalam penilaian laba komprehensif.

\section{Metode Penelitian}

Penelitian tentang penyajian pendapatan komprehensif lain dan komponennya pada industri perdagangan, jasa, dan investasi dilakukan dengan memperoleh data sekunder antara lain di Bursa Efek Indonesia. Data sekunder yang diperoleh berfokus pada emitenemiten pada perusahaan industru perdagangan, jasa, dan investasi. Selain itu penelitian ini juga menggunakan studi dokumentasi dan dari berbagai sumber.
Penelitian ini menggunakan metode deskriptif kuantitatif, yaitu mengamati dan menganalisis objek penelitan yang terdiri dari komponen-komponen pada laporan koprehensif lain (OCI) pada sub sektor industri perdagangan, jasa, dan investasi. Data kuantitatif berupa angka-angka dan data diolah menggunakan uji beda. Sebelum dilakukan uji beda, mentabulasi angka serta memberikan gambaran baru serta teori baru atau membenarkan teori sebelumnya, karena penelitian ini melalui suatu proses pengujian empiris. Waktu penelitian dilakukan pada laporan keuangan khususnya laporan pendapatan komprehensif dan pendapatan komprehensif lain berserta komponennya pada industri perdagangan, jasa, dan investasi yang terdaftar pada Bursa Efek Indonesia(BEI) periode tahun 2012-2015. Penelitian ini merupakan pengembagan dari penelitian sebelumnya yang dilakukan Sakirman (2016) tentang pengaruh income, daya informasi, pendapatan komprehensif lain terhadap return sahan dengan kualitas audit sebagai variable pemoderasi. Pengembangan penelitian dilakukan fokus pada komponen-komponen pandapatan komprehensif lain (OCI) pada industri perdagangan, jasa, dan investasi.

Sugiono (2009;35) mengatakan bahwa populasi adalah wilayah generalisasi yang terdiri atas objek/subjek yang mempunyai kualitas dan karakteristik tertentu yang diterapkan oleh peneliti untuk dipelajari dan ditarik kesimpulan. Adapun yang meenjadi populasi dalam penelitian ini adalah seluruh laporan keuangan emiten pada sub sector industri perdagangan, jasa, dan investasi yang terdaftar dalam Bursa Efek Indonesia (BEI). Dalam pengambilan data laporan keuangan yang mempunyai kriteria perusahaan yang aktif pada Bursa Efek Indonesia (BEI) kemudian juga perusahaan dengan data zero maupun non zero pada pendapatan komprehensif lain.

Metode pengumpulan data yang dilakukan dengan cara mendokumentasikan dari laporan keuangan tahunan perusahaan pada sub sektor 
perdagangan, jasa, dan investasi yang berfokus pada laporan pendapatan komprehensif terutama pendapatan komprehensif lain (OCI). Pengambilan data dilakukan dengan mengakses weside Bursa Efek Indonesia (BEI) (http;// ww.idx.co.id). Laporan keuangan yang diambil untuk diolah dan disajikan adalah laporan keuangan yang telah sesuai setelah konvergensi IFRS. Periode yang disajikan adalah laporan pendapatan komprehensif lain pada tahun 2012 sampai dengan 2015.

Jogianto (2004;22) mengklasifikasikan penelitan berdasarkan tujuan penelitian, karakteristik masalah, dan jenis data. Berdasarkan tujuan, penelitan kali ini merupakan penelitan dasar yang bertujuan untuk mengembangkan teori. Pengembangan teorinya menggunakan penelitian induktif. Penelitian induktif yaitu penelitian yang bertujuan untuk mengembangkan (generating) teori melalui pengungkapan fakta.

Berdasarkan karakteristik masalah, penelitian kai ini termasuk dalam penelitian deskriptif, yaitu pengumpulan data untuk menjawab pertanyaan mengenai status akhir dari objek terakhir dari objek penelitian. Analisis dilakukan selama kurun waktu waktu empat tahun yaitu 2012 sampai dengan 2015. Hasil penelitian ini diharapkan dapat menjadi pengembangan sebelumnya dan lebih spesifik pada komponenkomponen pendapatan komprehensif lain, dan lebih focus lagi pada masing-masing perusahaan sub sektor perdagangan, jasa, dan investasi.

Berdasarkan sifat dan jenis datanya, penelitian menggunakan data sekunder sebagai sumber datanya dan penelitian arsip. Data sekunder merupakan data yang diporoleh dalam bentuk sudah jadi (tersedia) melalui publikasi dan informasi yang dikeluarkan dari berbagai organisasi atau perusahaan-perusahaan publik yang terdaftar di Burssa Efek Indonesia. Dalam mendukung penelitian ini jenis data yang digunakan adalah data sekunder. Data sekunder merupakan data yang diperoleh dengan menggunakan data dari Bursa Efek Indonesia
(BEI) serta literatur kepustakaan lainnya untuk kemudian dibagikan pada subjek-subjek penelitian, dalam hal ini adalah para emiten yang terdaftar pada Bursa Efek Indonesia (BEI) secara aktif pada industri perdagangan, jasa, dan investasi.

Dalam penelitian ini uji beda dilakukan dengan mengukur dengan mengukur status skor pada tiap butir (item) berdasarkan dari laporan keuangan yang disajikan pada sub sektor industri perdagangan, jasa, dan investasi. Uji beda dilakukan untuk mengetahui lebih dalam terhadap status status yang diberikan untuk masing-masing komponen perubahan Komponen-komponen dalam pendapatan komprehensif lain (OCI) akan membentuk score dengan penjabaran yang telah ditetapkan. Semakin tinggi hasil penilaian daya informasi yang dihasilkan maka semakin mempunyai pengaruh positif terhadap informasi yang dihasilkan, maka dari itu pendapatan komprehensif lain (OCI) dan komponennya dinyatakan dalam:

OCI $=1$ PSAK 10 Perubahan selisih kurs mata uang asing;

$\mathrm{OCI}=2$ PSAK 24 Program imbalan kerja;

OCI $=3$ PSAK 55 Perubahan investasi aset keuangan tersedia untuk dijual;

$\mathrm{OCI}=4$ PSAK 55 Lindung Nilai Kas;

OCI $=5$ PSAK 16/19 Relevansi aset tetap berwujud dan tidak berwujud;

$\mathrm{OCI}=6$ PSAK 15 Asosiasi dan;

$\mathrm{OCI}=7$ PSAK 15 Ventura.

Kurs mata uang asing adalah komponen terhadap adanya transaksi dalam bentuk mata uang asing yang akan dikonversi pada mata uang rupiah pada ahir periode tertentu. Apabila perusahaan ada menggunakan kurs mata uang asing kemungkinan transaksi terhadap keuntungan dan kerugian akan transaksi mata uang asing akan tercatat. Hal tersebut akan terlihat dari masing-masing perusahaan dengan sub sektor industri perdagangan, jasa, dan investasi.

Revaluasi aset tetap bewujud adalah suatu metode pencatatan apabila perusahaan 
menggunakan fair value terhadap pencatatan nilai aset tetapnya. Kebijakan ini tergantung dari masing-masing perusahaan. Dalam hal revaluasi aset tetap akan dihitung oleh pihak penalai independen. Revaluasi aset tidak berwujud juga merupakan suatu metode pencatatan apabila perusahaan menggunakan metode fair value terhadap pencatatan nilai aset tetap tidak berwujudnya. Kebijakan ini tergantung dari masing-masing perusahaan, terutama dala hal satu transaksi sehingga akan muncul aset tetap tidak berwujud. Dalam hal revaluasi aset tetap tidak berwujud akan dihitung juga oleh pihak penilai independen.

Program imbalan kerja merupakan program kewajiban pencadangan bagi perusahaan terhadap hak-hak karyawan yang akan dibayarkannya dikemudian hari apabila karyawan tersebut diberhentikan ataupun pensiun. Dalam program ini dihitung oleh pihak aktuaris. Dalam hal perhitungannnya akan muncul keuntungan dan kerugiannya.

Lindung nilai adalah jumlah lindung nilai atas arus kas yang berhubungan langsung dengan tingkat resiko suatu perusahaan memiliki nilai yang diperoleh setelah dibandingkan dengan total aset dari perusahaan. Hal tersebut mencerminkan bahwa dari keseluruhan aset yang dimiliki perusahaan memiliki presentase aset yang dilindung nilai, yang mengidentifikasikan adanya resiko dari perusahaan tersebut.

Asosiasi dan ventura adalah lebih pada adanya transaksi pada investasi terhadap entitas lain dimana sebagai investor perusahaan mempunyai pengaruh signifikan dan bukan merupakan entitas anak.

Analisis data dilakukan melalui Uji beda yang penyajiannya dilakukan dengan $\mathrm{Uji}$ Cramer V, hal tersebut dikarenakan data yang digunakan berskala nominal. Dalam pengujian ini tidak memerlukan asumsi normalitas karena dalam penelitian ini termasuk kelompok statistic non-parametric.

\section{Analisis Hasil dan Pembahasan}

Penelitian ini bertujuan menganalisis penyajian other comprehensive income dan komponennya pada industri perdagangan, jasa, dan investasi pasca penerapan IFRS di Indonesia. Studi empiris dilakukan pada sector industri perdagangan, jasa, dan investasi yang terdaftar di Bursa Efek Indonesia tahun 2012-2015, dengan objek penelitian komponen revaluasi aset tetap (PSAK 16/19), penjabaran laporan keuangan mata uang asing ke mata uang pelaporan (PSAK 10), perubahan aktuarial dalam imbalan kerja manfaat pasti (PSAK 24), perubahan nilai wajar dalam investasi yang tersedia untuk dijual dan perubahan nilai wajar terhadap lindung nilai arus kas - available for sale and hedging (PSAK 55), asosiasi dan ventura (PSAK 15).

Tabel 1. Perkembangan Penyajian OCI 2012-2015

\begin{tabular}{lrrrr}
\hline \multirow{2}{*}{ KOMPONEN OCI } & \multicolumn{4}{c}{ PENYAJIAN (\%) } \\
& $\mathbf{2 0 1 2}$ & $\mathbf{2 0 1 3}$ & $\mathbf{2 0 1 4}$ & $\mathbf{2 0 1 5}$ \\
\hline PSAK 10 - Selisih Kurs & $20.20 \%$ & $21.50 \%$ & $23.40 \%$ & $22.40 \%$ \\
PSAK 24 - Imbalan Kerja & $6.10 \%$ & $6.50 \%$ & $84.70 \%$ & $93.50 \%$ \\
PSAK 55 - AFS & $14.10 \%$ & $14.00 \%$ & $14.40 \%$ & $17.80 \%$ \\
PSAK 55 - Heding & $2.00 \%$ & $2.80 \%$ & $4.50 \%$ & $7.50 \%$ \\
PSAK 16/19 - Rev. Aset & $1.00 \%$ & $2.80 \%$ & $1.80 \%$ & $7.50 \%$ \\
PSAK 15 - Asosiasi & $2.00 \%$ & $2.80 \%$ & $3.60 \%$ & $5.60 \%$ \\
PSAK 15 - Ventura & $0 \%$ & $0 \%$ & $0 \%$ & $0 \%$ \\
\hline
\end{tabular}


Penyajian Other Comprehensive Income (OCI) terkait PSAK 10 tentang Selisih Kurs pada laporan laba rugi dan penghasilan komprehensif lain mengalami peningkatan/penurunan selama periode waktu observasi. Selama 4 tahun dalam pengamatan bahwa $21,9 \%$ perusahaan melakukan penyajian PSAK10 tentang Selisih Kurs. Sedangkan berdasarkan penyajiannya selama 4 (empat) tahun pengamatan sub sektor industri perusahaan investasi paling banyak menyajikan akun tersebut yakni sebesar 63,2\%.

Penyajian Other Comprehensive Income (OCI) terkait selisih imbalan kerja pada laporan laba rugi dan penghasilan komprehensif lain mengalami peningkatan/penurunan selama periode waktu observasi. Selama 4 (empat) tahun pengamatan bahwa 48,8\% perusahaan melakukan penyajian selisih imbalan kerja. Berdasarkan penyajiannya selama 4 (empat) tahun pengamatan sub sektor industri jasa komputer dan perangkatnya paling banyak menyajikan akun tersebut sebanyak $65,0 \%$.

Penyajian Other Comprehensive Income (OCI) terkait selisih nilai sekuritas yang tersedia untuk dijual pada laporan laba rugi dan penghasilan komprehensif lain mengalami peningkatan/penurunan selama periode waktu observasi. Selama 4 (empat) tahun pengamatan bahwa $15,1 \%$ perusahaan melakukan penyajian selisih nilai sekuritas tersedia untuk dijual. Berdasarkan penyajiannya bahwa sub sektor industri perusahaan investasi dengan nilai paling banyak menyajikan akun tersebut sebanyak 42,1 $\%$.

Penyajian Other Comprehensive Income (OCI) terkait selisih nilai lindung nilai/Hedging yang tersedia untuk dijual pada laporan laba rugi dan penghasilan komprehensif lain mengalami peningkatan / penurunan selama periode waktu observasi. Selama 4 (empat) tahun pengamatan $4,2 \%$ perusahaan melakukan penyajian selisih nilai lindung nilai/Hedging. Berdasarkan penyajiannya PSAK 55 tentang Lindung Nilai/ Hedging sub sektor industri perdagangan besar barang produksi paling banyak menyajikan akun tersebut sebanyak $9,3 \%$.

Penyajian Other Comprehensive Income (OCI) terkait Selisih nilai Aset/Aset Tidak Berwujud pada laporan laba rugi dan penghasilan komprehensif lain mengalami peningkatan / penurunan selama periode waktu observasi. Selama 4 (empat) tahun pengamatan 3,3\% perusahaan melakukan penyajian selisih nilai Aset/Aset Tidak Berwujud. Berdasarkan penyajiannya bahwa sub sektor industri kesehatan paling banyak menyajikan akun tersebut sebanyak $9,1 \%$.

Penyajian Other Comprehensive Income (OCI) terkait Selisih Nilai Asosiasi pada laporan laba rugi dan penghasilan komprehensif lain mengalami peningkatan/ penurunan selama periode waktu observasi. Selama 4 (empat) tahun pengamatan 3,5\% perusahaan melakukan penyajian Selisih Nilai Asosiasi. Berdasarkan penyajiannya bahwa sub sektor industri jasa komputer dan perangkatnya paling banyak menyajikan akun tersebut sebesar 20,0\%.

Penyajian Other Comprehensive Income (OCI) terkait selisih nilai ventura pada laporan laba rugi dan penghasilan komprehensif lain selama 4 (empat) tahun pengamatan seluruh perusahaan tidak melakukan penyajian selisih nilai ventura. 
Tabel 2. Rangkuman Hasil Pengujian Hipotesis $1 \mathrm{~s} / \mathrm{d}$ Hipotesis 7

Sektor Industri Perdagangan, Jasa, dan Investasi 2012-2015

\begin{tabular}{llcrr}
\hline No & Komponen & Prob. & Keterangan & \\
\hline 1 & Selisih Kurs (PSAK 10) & 0,000 & Signifikan & Beda \\
2 & Imbalan Kerja (PSAK 24) & 0,679 & Tidak Signifikan & Tidak Beda \\
3 & Sekuritas Tersedia Dijual (PSAK 55) & 0,000 & Signifikan & Beda \\
4 & Hedging (PSAK 55) & 0,016 & Signifikan & Beda \\
5 & Revaluasi Aset (PSAK 16/19) & 0,339 & Tidak Signifikan & Tidak Beda \\
6 & Asosiasi (PSAK 15) & 0,001 & Signifikan & Beda \\
7 & Ventura (PSAK 15) & na & - & Tidak dapat \\
& & & & disimpulkan \\
\hline
\end{tabular}

Black (2016) memberikankan petunjuk arah penelitian terkait penghasilan komprehensif lain identifkasi jenis-jenis akun yang paling sering disajikan berdasarkan kelompok imdustri. Identifikasi tersebut penting untuk mengetahui komponen manakah yang dominan untuk kondisi micro ekonomi dan makro ekonomi. Apakah penghasilan komprehentif lain dimanfaatkan sebagai bahan pertimbangan untuk mengambil keputusan terkait finansiall ekonomi-ekonomi mikro maupun makro oleh investor, manajer, direksi, dan dewan komisaris.Standar akuntansi untuk penghasilan komprehensif penting untuk disebarkan agar ada harmonisasi perlakuan akuntansi.

\section{Simpulan, Keterbatasan, dan Implikasi Hasil Penelitian}

Pengujian hipotesis untuk menguji perbedaan penyajian 7 (tujuh) komponen other comprehensive income (OCI) memberikan bukti bahwa 2 (dua) hipotesis terbukti dan 4 (tiga) tidak berhasil dibuktikan. selisih kurs, sekuritas lindung nilai, asosiasi ditemukan adanya perbedaan penyajian pada laporan laba rugi dan penghasilan komprehensif lain. Hipotesis terkait dengan imbalan pasti, aset/aset tidak berwujud tidak ditemukan adanya perbedaan penyajian pada laporan laba rugi dan penghasilan komprehensif lain. Hipotesis ventura bersama tidak dapat disimpulkan karena sampel yang diuji secara keseluruhan tidak menyajikan selisih nilai ventura.

Keterbatasan penelitian ini adalah mengambil satu kelompok sampel sektor industri beserta dengan subsektor-subsektor di dalamnya. Hasil observasi hanya berlaku untuk sektor industri tersebut dan tidak berlaku untuk sektor industri lain yang terdaftar di Bursa Efek Indonesia (BEI). Demikian juga dengan hasil uji beda, temuan perbedaan tidak dapat digeneralisasi untuk keseluruhan sektor industri. Hasil penelitian ini merupakan informasi penting yang dapat digunakan pemerintah sebagai salah satu informasi pendapatan pajak karena selisih nilai komponen Other Comprehensive Income (OCI) dapat dikenai pajak. Bagi investor, hasil penelitian ini memberikan informasi tentang besarnya nilai Other Comprehensive Income (OCI) dimana nilai OCI meskipun secara riil bukan berupa kas namun nilai tersebut dapat merupakan informasi yang mampu menambah nilai perusahaan, misalnya terkait dengan peningkatan nilai asset tetap yang tercermin pada revaluasi asset. Sedangkan bagi peneliti berikutnya, hasil penelitian ini merupakan dasar dilakukannya riset-riset lanjutan terkait Other Comprehensive Income (OCI). Faktor apa yang mempengaruhi OCI dan konsekuensi yang diakibatkan oleh informasi OCI. 


\section{Daftar Referensi}

Ahalik, (2015), PSAK terkini Berbasis IFRS Terkait OCI vs SAK ETAP, Jakarta

Anggraeni, R., \& Jogiyanto Hartono, M. (2017). Relevansi Nilai Komponen Penghasilan Komprehensif Lain (Doctoral Dissertation, Universitas Gadjah Mada).

Black, D. E. (2016). Other Comprehensive Income: A Review and Directions For Future Research. Accounting \& Finance, 56(1), 9-45.

Bratten, B., Causholli, M., \& Khan, U. (2016). Usefulness Of Fair Values For Predicting Banks' Future Earnings: Evidence From Other Comprehensive Income And Its Components. Review $f$ Accounting Studies, 21(1), 280-315.

Brigham, Eugene F, \& Houston, Joef F. (2011), dasar-dasar manajemen Keuangan, terjemahan, Edisi 10, Jakarta, Salemba Empat

Du, N., Stevens, K., \& McEnroe, J. (2015). The effects of comprehensive income on investors' judgments: An investigation of one-statement vs. two-statement presentation formats. Accounting Research Journal, 28(3), 284-299.

Gazzola, P., \& Amelio, S. (2014). The impact of comprehensive income on the financial ratios in a period of crises. Procedia Economics and Finance, 12, 174-183.

Günther, R. (2015). Value-Relevance of Other Comprehensive Income under IFRS. University of St. Gallen, St. Gallen.

Huang, H. W., Lin, S., \& Raghunandan, K. (2015).

The volatility of other comprehensive income and audit fees. Accounting Horizons, 30(2), 195-210.

Kim, J. H. (2016). Presentation formats of other comprehensive income after accounting standards update 2011-05. Research in Accounting Regulation, 28(2), 118-122.

Nishikawa, I., Kamiya, T., \& Kawanishi, Y. (2016). The definitions of net income and comprehensive income and their implications for measurement. Accounting Horizons, 30(4), 511-516.
Nugroho, M. H., \& Januarti, I. (2016). Pengaruh Laba Rugi Dan Penghasilan Komprehensif Lain Terhadap Return Saham Dengan Kualitas Audit Sebagai Variabel Moderasi Di Indonesia (Doctoral Dissertation, Fakultas Ekonomika Dan Bisnis).

Praptias, D., \& Harto, P. (2016). Relevansi Nilai Dari Comprehensive Income (Studi Empiris Pada Perusahaan Non Keuangan Yang Terdaftar Di Bursa Efek Indonesia Tahun 2012-2014) (Doctoral Dissertation, Fakultas Ekonomika Dan Bisnis).

Prihadi, Toto. (2011). Analisis Laporan Keuangan Teori dan Aplikasi, PPM. Jakarta. Santoso, Y. D., Ahmar, N., \& Mulyadi, J. M. V. (2017). Penyajian Pendapatan Komprehensif Lain Dan Komponennya Pada Industri Keuangan. Liquidity, 6(1), 19-31.

Schaberl, P. D., \& Victoravich, L. M. (2015). Reporting Location and The Value Relevance Of Accounting Information: The Case Of Other Comprehensive Income. Advances in Accounting, 31(2), 239-246.

Shi, L., Wang, P., \& Zhou, N. (2017). Enhanced disclosure of other comprehensive income and increased usefulness of net income: The implications of Accounting Standards Update 2011-05. Research in Accounting Regulation, 29(2), 139-144.

Sidantha, B., Ahmar, N., \& Mulyadi, J. M. V. (2018).PenyajianPendapatanKomprehensif Lain: Investigasi Pada Industri Infrastruktur Dan Utilitas. Jiafe| Jurnal Ilmiah Akuntansi Fakultas Ekonomi, 2(2), 59-71.

Wahyudi, I. (2017). Investigasi Other Comprehensive Income Pada Industri Paska Implementasi IFRS 2012 (Studi Empiris Pada Perusahaan Industri Yang Terdaftar Di Bursa Efek Indonesia Periode 2012-2015).

Yudiman, A. T., \& Ahmar, N. (2017). Relevansi Nilai Net Income, Comprehensive Income dan Other Comprehensive Income Pada Perusahaan Manufaktur. Jurnal Ilmiah Professional Indonesia, 1(1), 1-16. 